\title{
Impacts of the invasive ascidian Didemnum vexillum on green-lipped mussel Perna canaliculus aquaculture in New Zealand
}

\author{
Lauren M. Fletcher ${ }^{1,2, *}$, Barrie M. Forrest ${ }^{1}$, James J. Bell ${ }^{2}$ \\ ${ }^{1}$ Cawthron Institute, Private Bag 2, Nelson 7010, New Zealand \\ ${ }^{2}$ School of Biological Sciences, Victoria University of Wellington, PO Box 600, Wellington 6140, New Zealand
}

\begin{abstract}
Biofouling can pose a significant threat to shellfish aquaculture, as fouling organisms are often strong spatial competitors that are able to reach high densities or biomass in relatively short time frames. This study investigated the potential impacts of the colonial ascidian Didemnum vexillum on cultured New Zealand green-lipped mussels Perna canaliculus at one farm in the Marlborough Sounds region. Three size classes of mussels were examined: small (20 to $40 \mathrm{~mm}$ shell length at deployment), medium (40 to $60 \mathrm{~mm}$ ), and large (60 to $70 \mathrm{~mm}$ ). Replicate $4 \mathrm{~m}$ mussel lines were assigned to 1 of 3 treatments: (1) ambient fouling, (2) fouling enhanced by $D$. vexillum fragment inoculation (in addition to ambient fouling), or (3) control lines that were kept free of $D$. vexillum. After $15 \mathrm{mo}$, subsections of lines $(0.5 \mathrm{~m}$ length) were processed to determine the effects of fouling cover on mussel density within lines, as well as on individual mussel size and condition. A highly significant negative relationship was shown between $D$. vexillum biomass and mussel density for small mussels, and to a lesser extent for medium mussels. Values of mussel condition indices were similar across size classes and across fouling treatments within each size class. These results indicate that mussels may only be vulnerable to direct $D$. vexillum fouling impacts at early stages of production, and that impacts may be restricted to displacement of mussels as opposed to reduced size and condition. This information will assist in the implementation of management procedures through increased understanding of $D$. vexillum effects at different stages of mussel production.
\end{abstract}

KEY WORDS: Biofouling $\cdot$ Exotic species $\cdot$ Condition index $\cdot$ Non-indigenous species $\cdot$ Bivalve aquaculture $\cdot$ Tunicate

\section{INTRODUCTION}

Marine aquaculture is the world's fastest growing primary sector, providing an essential food resource to a rising world population. An inherent issue in the commercial culture of marine species is that submerged surfaces are colonised by a range of organisms, a process termed biofouling (Railkin 2004). Biofouling accumulation can pose a significant threat to marine aquaculture industries, with many biofouling species being strong spatial competitors that can

*Email: lauren.fletcher@cawthron.org.nz reach very high densities or biomass over relatively short periods (Dealteris et al. 2004, Blum et al. 2007). Negative effects of biofouling in aquaculture can include impacts to cultured species directly, impacts to infrastructure (immersed structures such as cages, netting and pontoons), as well as associated environmental impacts on local ecosystems. The costs associated with biofouling are believed to be substantial, but are often difficult to quantify. In addition to revenue lost through effects on crop (e.g. Jeffs \& Stanley 2010), there are a number of direct costs associated

() The authors 2013. Open Access under Creative Commons by Attribution Licence. Use, distribution and reproduction are unrestricted. Authors and original publication must be credited. 
with control and mitigation efforts (Adams et al. 2011). Conservative estimates of direct economic losses attributed to biofouling within the European aquaculture industry have been appraised at 5 to $10 \%$ of the industry value (Lane \& Willemsen 2004), and more specifically up to 20 and $30 \%$ of final market price for oysters (Enright 1993) and scallops (Claereboudt et al. 1994), respectively.

Direct impacts of biofouling on marine aquaculture can vary considerably depending on the species cultured and the method of culture (reviewed by Fitridge et al. 2012), the geographic location, and local environmental conditions. Commercial shellfish culture appears to be particularly prone to biofouling due to the creation of complex novel substrates that arise through the combination of bivalve shells and artificial structures (McKindsey et al. 2007). In addition, farm structures are usually suspended and may be protected from predation, thereby providing a refuge for biofouling organisms (Rocha et al. 2009). The overall composition and biomass of biofouling communities is spatially and temporally variable (Woods et al. 2012). Communities are generally characterised by the presence of a variety of sessile, suspensionfeeding invertebrates including ascidians, bivalves, hydroids, bryozoans, and cnidarians, as well as an array of macroalgae (Scheer 1945), and may include non-indigenous species. While there are instances where biofouling presence has not been found to adversely affect shellfish culture (e.g. Arens et al. 2011), the presence of fouling species, particularly large aggregations, is in most cases seen as detrimental to these activities.

Ascidians are among the most prolific and devastating biofoulers to shellfish aquaculture operations globally (Lambert 2007, Adams et al. 2011). Negative effects on production caused by ascidian fouling can include crop losses through additional weight placed on shellfish species (Boothroyd et al. 2002, Thompson \& MacNair 2004, Ramsay et al. 2008), as well as impacts on general operations within farms, as high ascidian cover can impede the efficiency of processing equipment (Davis \& Davis 2010). Cultured shellfish are also particularly vulnerable to interference competition from overgrowth; colonial ascidians often create a physical barrier, compromising the opening of shellfish valves and reducing the availability of food to the shellfish underneath (Lesser et al. 1992, Lodeiros \& Himmelman 1996). Furthermore, direct competition for food resources has been demonstrated between ascidians and cultivated shellfish, including several species of oysters (Riisgård et al. 1995), mussels (Le Blanc et al. 2003,
Daigle \& Herbinger 2009), and scallops (Ross et al. 2004, Su et al. 2008).

Currently, several introduced ascidians threaten New Zealand's highly valued green-lipped mussel Perna canaliculus industry, and efforts to control and manage these species are ongoing. Relatively low profit margins in this industry mean that the impacts of biofouling and expenditures associated with control can be very significant at the individual farm level. The recent human-mediated introduction of the invasive colonial ascidian Didemnum vexillum (Kott 2002) has led to negative effects on mussel culture within the Marlborough Sounds region (see Fig. 1), which is New Zealand's most important growing area for green-lipped mussels. Since first being detected in 2001, D. vexillum has been inadvertently spread within the region by anthropogenic transport mechanisms (Coutts \& Forrest 2007). D. vexillum colonies are capable of rapid growth and expansion through both sexual and asexual reproduction, and as such are able to quickly colonise large areas of artificial and natural substrata (e.g. Coutts \& Forrest 2007, Valentine et al. 2007b). This increased biomass can lead to the destabilisation of mussel crops and added weight on infrastructure, which has led to substantial mitigation and control costs (Pannell \& Coutts 2007).

In order to determine the cost-effectiveness of possible mitigation strategies, it is necessary to quantify actual impacts of biofouling species on shellfish culture and the causative factors. Blue mussels Mytilus edulis fouled by Didemnum vexillum in the northeast USA have been shown to have smaller shell lengths and lower condition values than those free of fouling within experimental systems (Auker 2010). However, there remains a lack of empirical data regarding the impacts of $D$. vexillum fouling within an industry setting, as previous work is primarily anecdotal. As long as evidence of impacts remains largely speculative, rational and fully informed management decisions cannot be made. The present study investigated the impacts of $D$. vexillum biofouling on the commercial culture of New Zealand green-lipped mussels. The effect of $D$. vexillum fouling on mussel survival was evaluated experimentally through assessment of mussel density on mussel line sections with varying levels of fouling cover. In addition, individual mussels were evaluated for effects of fouling on size and condition through measurement of a range of morphometric indices. Effects were quantified between 3 size classes of mussels, in order to determine whether some mussel life-stages or stages of the production cycle are more vulnerable to negative effects of $D$. vexillum overgrowth. 


\section{MATERIALS AND METHODS}

\section{Study site}

The experiment was carried out on a mussel farm located on the northern side of Fairy Bay $\left(41^{\circ} 07^{\prime} \mathrm{S}\right.$, $\left.173^{\circ} 52^{\prime} \mathrm{E}\right)$, situated within Pelorus Sound, which is part of the larger Marlborough Sounds system (Fig. 1). Pelorus Sound is a relatively deep (average depth: $\sim 40 \mathrm{~m}$ ), narrow, and highly indented system that is subject to freshwater input at its head from 2 rivers. Fairy Bay is located approximately $25 \mathrm{~km}$ from the head of the Sound. The mussel farm used for the experiment had previously been identified as having a well-established population of Didemnum vexillum.

\section{Set-up of experimental mussel lines}

Perna canaliculus mussels free of Didemnum vexillum fouling were collected on 21 November 2008

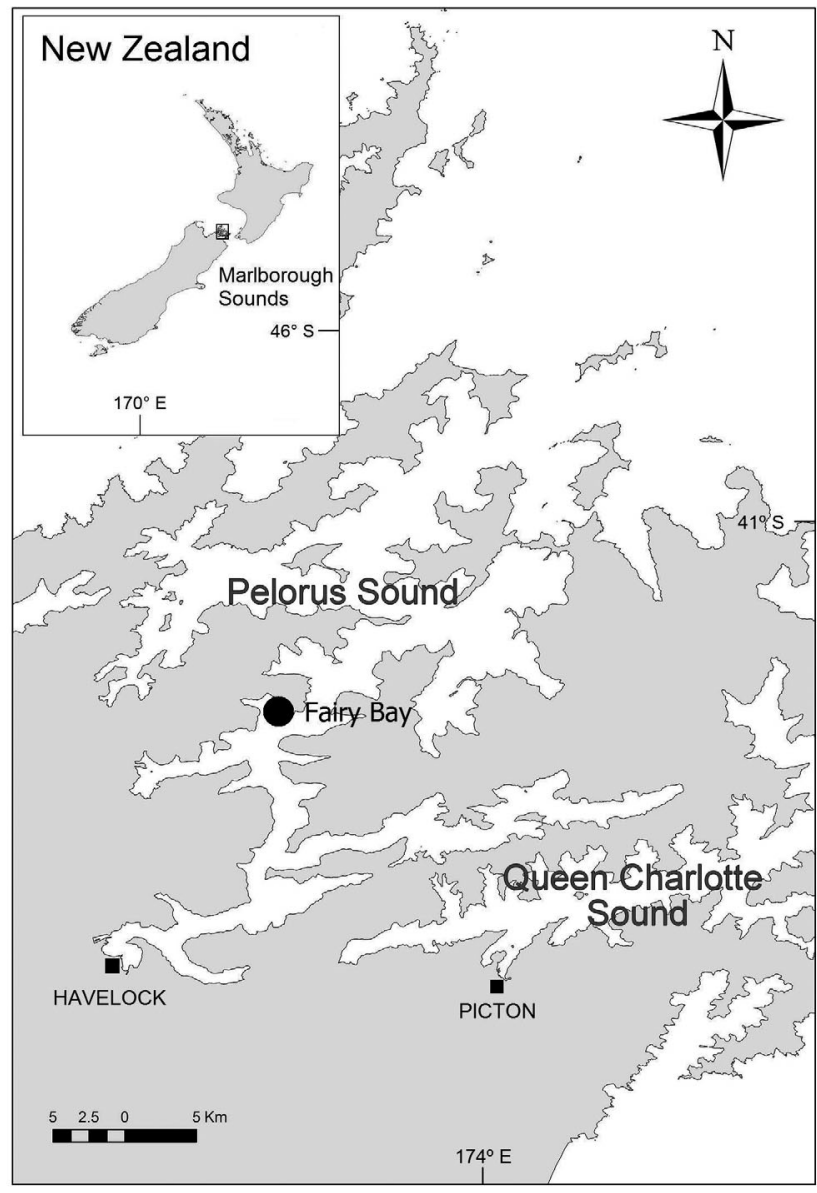

Fig. 1. Marlborough Sounds region (inset: location within New Zealand). The study site at Fairy Bay is indicated from nearby farms within Pelorus Sound. A continuous length of culture rope $(\sim 60 \mathrm{~m})$ was transplanted for each of the 3 mussel size classes: small (20 to $40 \mathrm{~mm}$ shell length), medium (40 to $60 \mathrm{~mm}$ ), and large (60 to $70 \mathrm{~mm}$ ) (Table 1). Following collection, each length of mussel rope was cut into 15 replicate $4 \mathrm{~m}$ lines (45 lines in total). There were approximately 670 mussels $\mathrm{m}^{-1}$ on each line within the small size class, and 140 and 150 mussels $\mathrm{m}^{-1}$ on the lines with medium and large mussels, respectively (Table 1). The medium and large mussels had been reseeded to reduce crowding as part of standard industry practice. Five replicate vertical lines of each of the 3 size classes were randomly assigned to each of $3 \mathrm{D}$. vexillum fouling treatments: (1) ambient fouling, in which lines were left to become naturally fouled by $D$. vexillum and other species; (2) ambient fouling enhanced with fragment inoculation, in which lines were artificially inoculated with $D$. vexillum colonies (hereinafter referred to as 'enhanced fouling') in an attempt to simulate 'worst-case' fouling; and (3) control lines, on which fouling was maintained at a very low level by removal of $D$. vexillum. Fragment inoculation was used as an enhanced fouling treatment method, as $D$. vexillum fragments have been demonstrated to attach to substrata and grow extremely rapidly (Valentine et al. 2007a, Morris \& Carman 2012). Replicate vertical lines of each treatment were randomly allocated along the 2 horizontal backbone ropes, with each line spaced approximately $25 \mathrm{~cm}$ apart.

The enhanced fouling treatment lines were inoculated on 28 November 2008. Medium-sized Didemnum vexillum fragments $\left(\sim 30 \mathrm{~cm}^{2}, \sim 50 \mathrm{~g}\right)$ were attached to the mussel lines using industry-supplied continuous tubular cotton mesh stocking. The stocking encased the mussel line with colony fragments inserted into the stocking approximately every $30 \mathrm{~cm}$. The stocking facilitated establishment of $D$. vexillum colonies by holding them in place on the mussels, and the cotton biodegraded after several weeks. Only the enhanced fouling treatment lines were encased in the cotton mesh stocking at this stage.

Table 1. Perna canaliculus. Average shell length $( \pm \mathrm{SE})$, meat weight $( \pm \mathrm{SE})$, and stocking density of mussels within each size class at the start of the experiment

\begin{tabular}{|lccc|}
\hline Size class & $\begin{array}{c}\text { Shell length } \\
(\mathrm{mm})\end{array}$ & $\begin{array}{c}\text { Meat } \\
\text { weight }(\mathrm{g})\end{array}$ & $\begin{array}{c}\text { Density } \\
\left(\text { ind. } \mathrm{m}^{-1} \text { ) }\right.\end{array}$ \\
\hline Small $(20-40 \mathrm{~mm})$ & $30.32 \pm 0.41$ & $2.16 \pm 0.08$ & $\sim 670$ \\
Medium $(40-60 \mathrm{~mm})$ & $53.91 \pm 0.49$ & $12.38 \pm 0.30$ & $\sim 140$ \\
Large $(60-70 \mathrm{~mm})$ & $64.28 \pm 0.48$ & $19.90 \pm 0.39$ & $\sim 150$ \\
\hline
\end{tabular}


Due to the large size of the mesh and temporary nature of the material, detrimental effects of this encasement on mussel growth and survival were not expected and were not controlled for. The D. vexillum colonies established from fragments had reached a considerable level of cover $6 \mathrm{wk}$ following initial inoculation of the lines (Fig. 2a,b).

The experiment ran for $15 \mathrm{mo}$, a period that included 2 austral summers (December to March), corresponding with periods of increased Didemnum vexillum growth and reproduction within this region (Fletcher et al. 2013). Water temperatures ranged
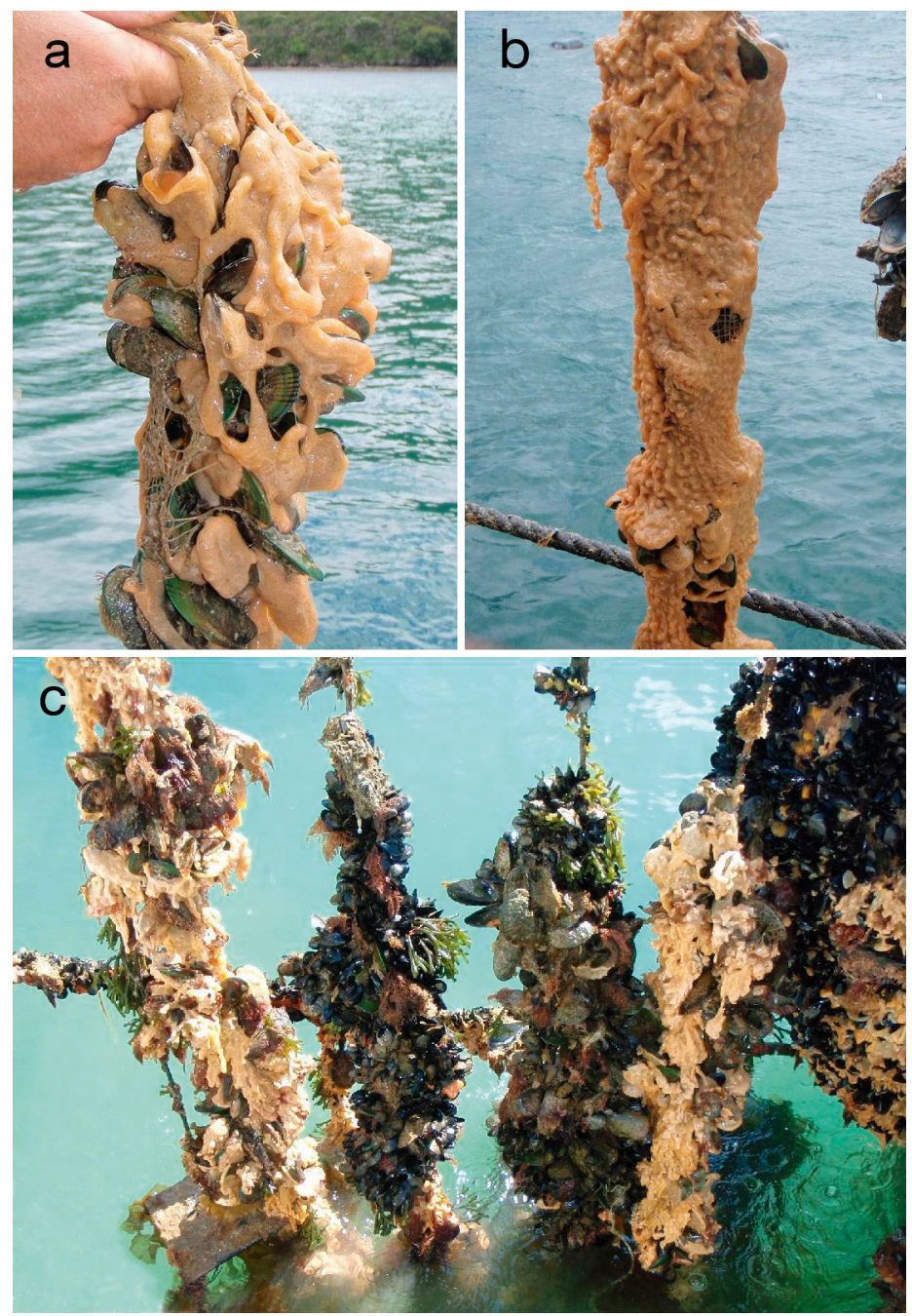

Fig. 2. Perna canaliculus and Didemnum vexillum. Set-up of experimental mussel lines. (a,b) Enhanced fouling treatment lines $6 \mathrm{wk}$ after inoculation with $D$. vexillum fragments on 28 November 2008. (c) Experimental lines on 29 January 2010, 14 mo after deployment. The 2 lines in the centre are from the control group, and the lines on the far left and far right are from the enhanced fouling group, highlighting the differences in $D$. vexillum biomass present between treatments. Photographs by L.M.F. from $8.3^{\circ} \mathrm{C}$ during winter months (June 2009) to $20.2^{\circ} \mathrm{C}$ in summer (February 2010). Control lines were treated to eliminate fouling 3 times over the course of the experiment: on 6 March 2009, 4 June 2009 and 29 January 2010. Treatment involved a combination of freshwater immersion and manual removal of colonies. Large $D$. vexillum colonies were removed by hand, after which the lines were completely immersed in freshwater (salinity: $\sim 3$ ) for $3 \mathrm{~h}$ within a $600 \mathrm{l}$ plastic bin, then returned to their original position on the backbone rope. Ideally, additional lines subjected to manual removal alone (as well as immersed in seawater for the same duration) would have been incorporated as a procedural control for the freshwater treatment; however, logistically this was not possible. In addition, short-duration freshwater immersion has been shown to be an effective method of $D$. vexillum removal (Denny 2008) that has no long-term detrimental effects on the survival or growth of Perna canaliculus (Forrest \& Blakemore 2006). The control lines were consistently free of appreciable fouling over the course of the experiment (Fig. 2c).

\section{Processing of mussel lines}

Collection and sample processing at the end of the 15 mo deployment was carried out during autumn (2 and 25 March 2010) at a time when Didemnum vexillum colony biomass was still at a seasonal high, and prior to mussel spawning and the loss of condition that was expected to occur during the June to July period (Fox 2003). Two replicate $4 \mathrm{~m}$ lines were lost during the experiment (large mussel control and large mussel ambient fouling), so final processing was carried out for 43 lines in total. One $0.5 \mathrm{~m}$ section was randomly selected from each line, and all mussels and $D$. vexillum colonies present within each section were removed. The upper parts of the lines, in the 0-1 m depth interval, were not sampled, as these mussels had been exposed to low salinity following several major storm events. The number and weight of mussels and $D$. vexillum colonies was recorded for each $0.5 \mathrm{~m}$ section sampled, and a random subsample of 20 mussels was collected and returned to the laboratory for analysis of mussel size and condition. To investigate effects of $D$. vexillum biomass on mussel density, additional $0.5 \mathrm{~m}$ 
sections were processed in the same manner for the $4 \mathrm{~m}$ lines that received ambient or enhanced fouling treatments.

\section{Mussel size and condition measurements}

A total of 860 mussels (20 mussels from 43 sections) were processed in randomly ordered batches over a $2 \mathrm{~d}$ period. A range of morphometric characteristics were measured, including shell length, whole wet weight, whole (live) volume, shell wet weight, halfshell weight of the cooked mussel, tissue cooked weight, and tissue dry weight. Measurements of shell length, whole wet weight, and live volume were completed initially, after which mussels were frozen and later thawed for further analysis. Once thawed, mussels were cooked in water at $95^{\circ} \mathrm{C}$ for $5 \mathrm{~min}$, then immersed in cold water for $2 \mathrm{~min}$, and left standing for a further 2 min to drain any excess water. Shell wet weight, half-shell weight and tissue cooked weights were measured separately using pre-weighed aluminium dishes. Dry tissue weights were recorded after drying at $80^{\circ} \mathrm{C}$ to a constant weight $(\sim 48 \mathrm{~h})$. All weights were recorded to the nearest $\pm 0.01 \mathrm{~g}$ and length measurements to the nearest $\pm 0.01 \mathrm{~mm}$. Mussel volume was recorded to the nearest $1.0 \mathrm{ml}$ (using a $250 \mathrm{ml}$ graduated measuring cylinder). Condition index (CI; Hickman \& Illingworth 1980) was calculated using the formula:

$$
\mathrm{CI}=\frac{\text { dry tissue weight }}{\text { whole (live) weight }- \text { shell wet weight }} \times 100
$$

In addition, an industry-applied green weight index (GWI; Fox 2003) was calculated using the formula:

$$
\text { GWI }=\frac{\text { cooked meat weight }}{\text { whole (live) weight }} \times 100
$$

\section{Statistical analysis}

Fouling effects on mussel density

Mussel loss for each $0.5 \mathrm{~m}$ section (expressed as a percentage of initial stocking density; see Table 1) was calculated to enable comparisons between size classes. Differences in mussel density, mussel weight and mussel loss among treatments were tested using a distance-based univariate permutational analysis of variance (PERMANOVA; Anderson 2001) based on Euclidean similarity matrices of the data. The experimental design comprised 2 factors: mussel size (fixed with 3 levels) and fouling treatment (fixed with 3 levels). The distribution of each individual variable was first examined for departures from normality and homogeneity of variance. Data were transformed, if necessary, to achieve approximate unimodal symmetry, to avoid right-skewness and to eliminate intrinsic mean-variance relationships. Each term in the analyses was tested using 4999 random permutations of the appropriate units. Significant terms were investigated using a posteriori pairwise comparisons with the PERMANOVA $t$-statistic and 999 permutations. For the ambient and enhanced fouling treatments, the effect of Didemnum vexillum biomass on mussel density within each size class was further investigated using linear regression analysis. D. vexillum biomass was treated as a continuous predictor variable, irrespective of fouling treatment, and the relationship with mussel density modelled. Due to the loss of lines during the experimental phase, both the PERMANOVA and regression analyses were run unbalanced.

\section{Fouling effects on size and condition}

Differences in mussel shell length, wet weight, and condition (CI and GWI) between experimental treatments were tested using univariate PERMANOVA as described in the previous paragraph. The experimental design comprised 3 factors: size (fixed with 3 levels), fouling treatment (fixed with 3 levels), and line (random and nested in the size $\times$ fouling treatment interaction). Due to the loss of lines during the experimental phase, only the data from 4 randomly chosen replicate lines were analysed. The effect of Didemnum vexillum biomass on mussel condition (CI and GWI) was examined through linear regression analysis (as described in the previous paragraph) for the effect on mussel density. As CI and GWI account for variations in mussel size, data were pooled across size classes for these regression analyses $(n=29$ sections). Permutational analyses of variance were performed using the software PRIMER 6 and PERMANOVA (Clarke \& Gorley 2006, Anderson \& Gorley 2007). All other analyses were carried out using the software package STATISTICA version 9.1 (StatSoft).

\section{RESULTS}

The level of Didemnum vexillum fouling present within the sections processed varied considerably between treatment lines. The average biomass present 
across all ambient fouling and enhanced fouling lines, irrespective of mussel size class, was comparable at the conclusion of the study $(0.67 \pm 0.10$ [SE] and $0.59 \pm$ $0.07 \mathrm{~kg} \mathrm{section}^{-1}$, respectively). Control lines were kept consistently free of $D$. vexillum fouling, and all sections had no colonies present at the time of sampling.

\section{Effects of Didemnum vexillum fouling on mussel density and weight}

There was a significant size class $\times$ fouling treatment interaction effect on both mean mussel density and mean mussel weight (Fig. 3, Table 2), driven by variation in fouling treatment effects between size classes. Pairwise comparisons indicated a significant effect of fouling treatment on both variables in the small size class, but not in the medium or large size classes ( $p<0.05$; Fig. 3). On average, the density of small size-class mussels was between 83 and $121 \%$ higher in the control treatment (247.8 \pm SE 24.2 mussels section ${ }^{-1}$ ) compared to the enhanced fouling and ambient fouling treatments $(135.2 \pm 17.9$ and $111.7 \pm$ 19.2 mussels section ${ }^{-1}$, respectively). Mussel weight followed a similar pattern, with the mean weight of small-sized mussels in the controls between 42 and $77 \%$ higher $(7.11 \pm 0.31 \mathrm{~kg})$ than in the enhanced fouling and ambient fouling treatments (5.02 \pm 0.44 and $4.01 \pm 0.58 \mathrm{~kg}$, respectively).

Percentage mussel loss varied significantly between size classes (Fig. 4, Table 2). Pairwise comparisons indicated significant differences in mussel loss between the small size class compared to both other size classes $(p<0.01)$; however, no overall effect of fouling treatment on mussel loss was detected $(\mathrm{p}>$ 0.05; Table 2). Although not significant ( $\mathrm{p}=0.08)$, the interaction effect indicated a variation in fouling effects between size classes, due to a greater loss of small mussels in the ambient fouling and enhanced fouling treatments $(66.8 \pm 5.7 \%$ and $59.8 \pm 5.3 \%$, respectively) compared with the small-mussel controls $(26.3 \pm 7.2 \%)$.

Linear regression analysis showed a strong and highly significant negative relationship between $D i$ demnum vexillum biomass and mussel density within the small mussels $\left(\mathrm{r}^{2}=0.631, \mathrm{p}<0.001\right.$; Fig. 5a). The model predicted $\sim 40 \%$ mussel loss for an increase of $1 \mathrm{~kg}$ of $D$. vexillum fouling per $0.5 \mathrm{~m}$ section. A similar but weaker relationship was evident in the medium size class $\left(\mathrm{r}^{2}=0.253, \mathrm{p}=0.024\right.$; Fig. 5b). In contrast, there was no relationship between $D$. vexillum biomass and mussel density for large mussels $\left(r^{2}=0.130, p=0.141\right.$; Fig. $\left.5 c\right)$.

\section{Effects of Didemnum vexillum fouling on mussel size and condition}

After 15 mo, mussels within the small size class were significantly smaller than the other 2 size classes. By contrast, mussels within the medium and large size classes were a similar size at the end of the experiment (Fig. 6). PERMANOVA analyses revealed highly significant effects of mussel size and replicate line (indicating spatial variability) on both the shell length and live weight of individual mussels
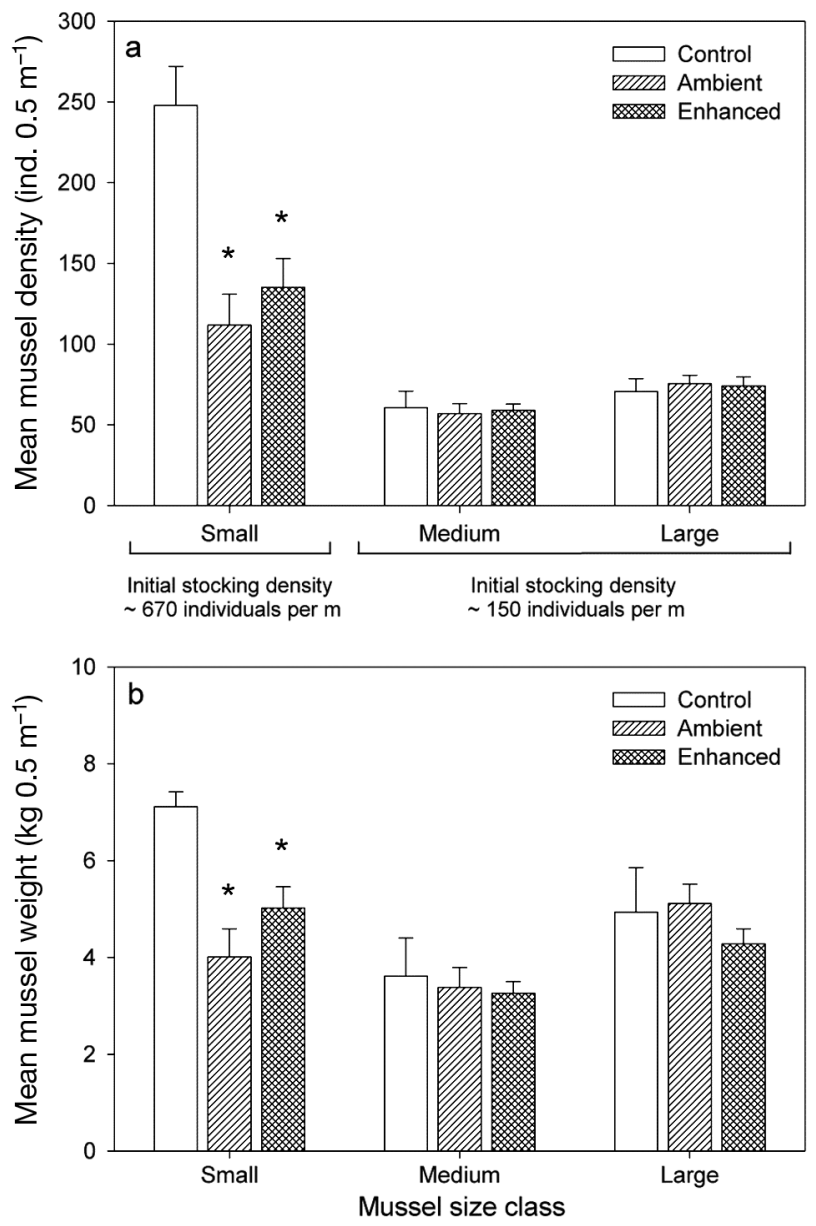

Fig. 3. Perna canaliculus. (a) Mean density and (b) mean combined weight $(+\mathrm{SE}, \mathrm{n}=10$ for ambient and enhanced treatments, and $n=5$ for controls, except for large size class with ambient treatment: $\mathrm{n}=8$, and large size class with control treatment: $\mathrm{n}=4$ ) of $P$. canaliculus present per $0.5 \mathrm{~m} \mathrm{sec-}$ tion of line for 3 size classes (small: $20-40 \mathrm{~mm}$ shell length at deployment, medium: $40-60 \mathrm{~mm}$, and large: $60-70 \mathrm{~mm}$ ) and 3 fouling treatments (controls, ambient fouling, and enhanced Didemnum vexillum fouling). Initial stocking densities of the size classes per metre of experimental line are indicated. *Significant fouling treatment effects (within mussel size class) in relation to control lines as indicated by pairwise comparisons $(t$-statistic, $\mathrm{p}<0.05)$ 
Table 2. Perna canaliculus. Permutational ANOVAs testing for mussel size class and fouling treatment effects on mean mussel density, mean combined mussel weight (see Fig. 3), and percentage of mussel loss over the 15 mo deployment (Fig. 4). Analyses based on Euclidean distances of the data, and each term was tested using 4999 random permutations of appropriate units.

Significant values $(\mathrm{p}<0.05)$ indicated in bold

\begin{tabular}{|c|c|c|c|c|c|c|c|c|c|c|}
\hline \multirow{2}{*}{$\begin{array}{l}\text { Source of } \\
\text { variation }\end{array}$} & \multirow[t]{2}{*}{ df } & \multicolumn{3}{|c|}{ —Density } & \multicolumn{3}{|c|}{ - Weight } & \multicolumn{3}{|c|}{ - Mussel loss - } \\
\hline & & MS & Pseudo- $F$ & $\mathrm{p}($ perm $)$ & MS & Pseudo- $F$ & $\mathrm{p}($ perm $)$ & MS & Pseudo- $F$ & $\mathrm{p}($ perm $)$ \\
\hline Size & 2 & 0.912 & 23.823 & $<0.01$ & 22.584 & 12.894 & $<0.01$ & 12636.00 & 28.112 & $<0.01$ \\
\hline Fouling & 2 & 0.095 & 2.476 & 0.089 & 6.037 & 3.447 & 0.038 & 802.08 & 1.785 & 0.177 \\
\hline Size $\times$ Fouling & 4 & 0.114 & 2.985 & 0.027 & 5.476 & 3.127 & 0.024 & 983.61 & 2.188 & 0.081 \\
\hline Residual & 63 & 0.038 & & & 1.751 & & & 449.47 & & \\
\hline Total & 71 & & & & & & & & & \\
\hline Transformation & & & $\log _{10}$ & & & None & & & None & \\
\hline
\end{tabular}

$(\mathrm{p}<0.01 ;$ Table 3). Pairwise comparisons indicated significant differences in both shell length and live weight between mussels in the small size class compared to both of the other size classes $(p<0.01)$, but not between the medium and large size classes for both shell length $(p=0.447)$ and live weight $(p=$ 0.640 ). No significant effect of fouling treatment was detected for either shell length ( $p=0.078$; Table 3 ) or live weight ( $p=0.359$; Table 3$)$. Although marginally non-significant, the interaction effects for both shell length and live weight $(\mathrm{p}=0.057$ and $\mathrm{p}=0.071$, respectively) indicated a variation in fouling effects between size classes. In particular, within the small size class, the shell length and live weight of indi-

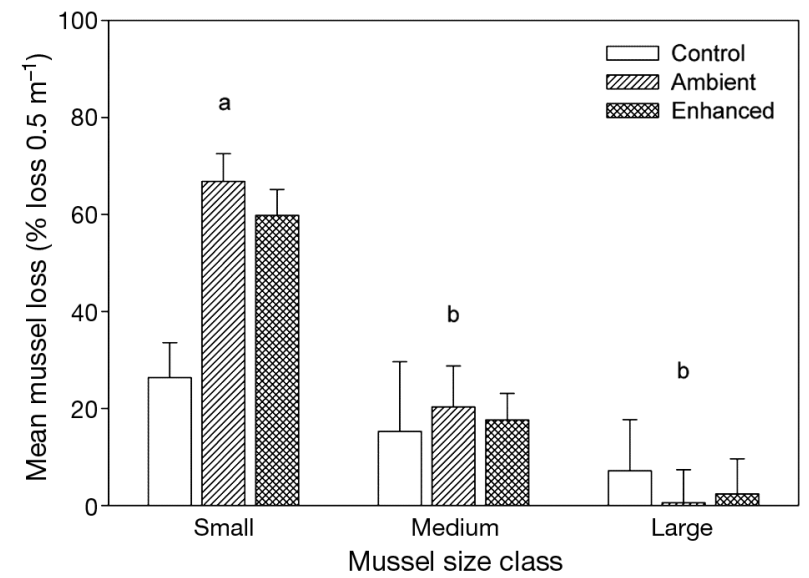

Fig. 4. Perna canaliculus. Mean mussel loss $(+\mathrm{SE}, \mathrm{n}=10$ for ambient and enhanced treatments, and $\mathrm{n}=5$ for controls, except for large size class with ambient treatment: $\mathrm{n}=8$, and large size class with control treatment: $\mathrm{n}=4$ ) per $0.5 \mathrm{~m} \mathrm{sec}$ tion of line for 3 size classes (small: $20-40 \mathrm{~mm}$ shell length at deployment, medium: $40-60 \mathrm{~mm}$, and large: $60-70 \mathrm{~mm}$ ) and 3 fouling treatments (controls, ambient fouling, and enhanced Didemnum vexillum fouling). Size classes sharing a letter indicate groupings from pairwise comparisons that were not significantly different from each other ( $t$-statistic, $\mathrm{p}>0.05)$
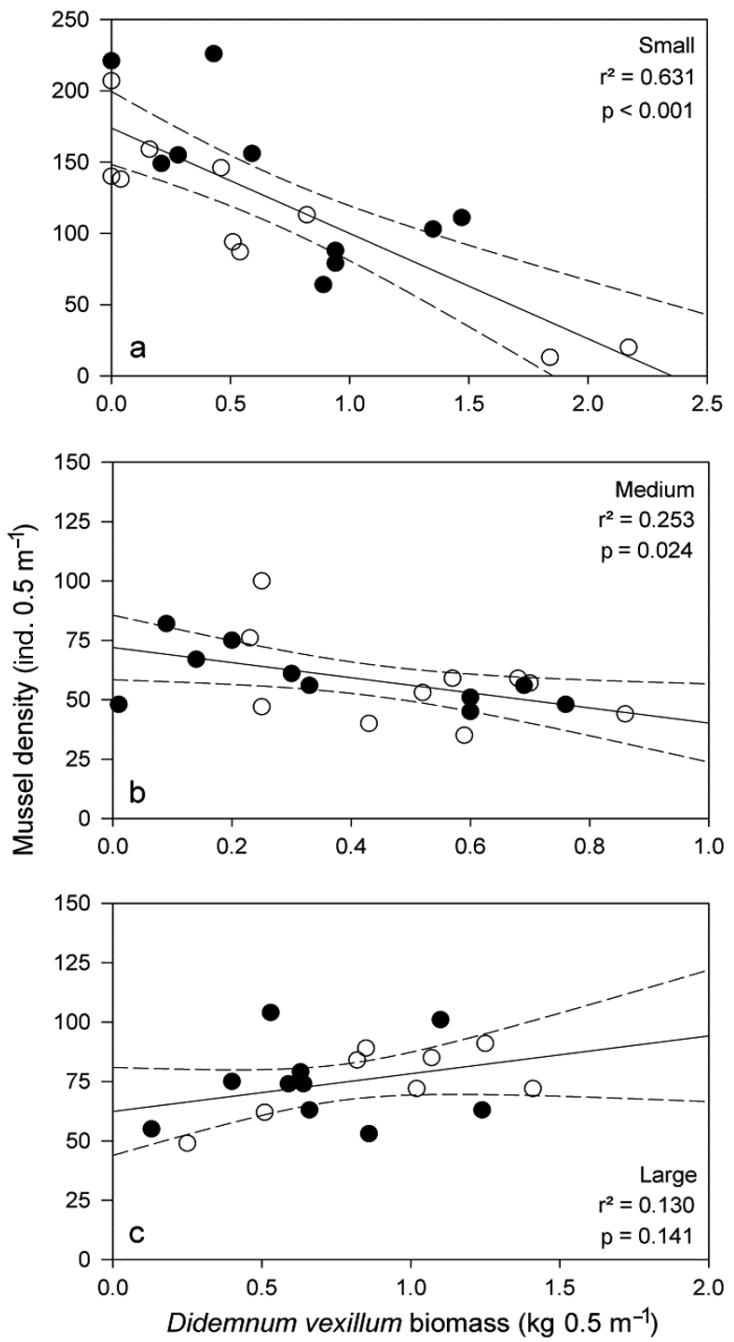

Fig. 5. Perna canaliculus and Didemnum vexillum. Relationship between mussel density and $D$. vexillum biomass per $0.5 \mathrm{~m}$ section for the (a) small $(20-40 \mathrm{~mm}$ shell length at deployment), (b) medium (40-60 mm), and (c) large (60-70 mm) size classes of mussels in the ambient fouling (O) and enhanced $D$. vexillum fouling $(\bullet)$ treatments. The $95 \%$ confidence intervals are shown (----). Note the differences in scales on the $x$ - and $y$-axes 

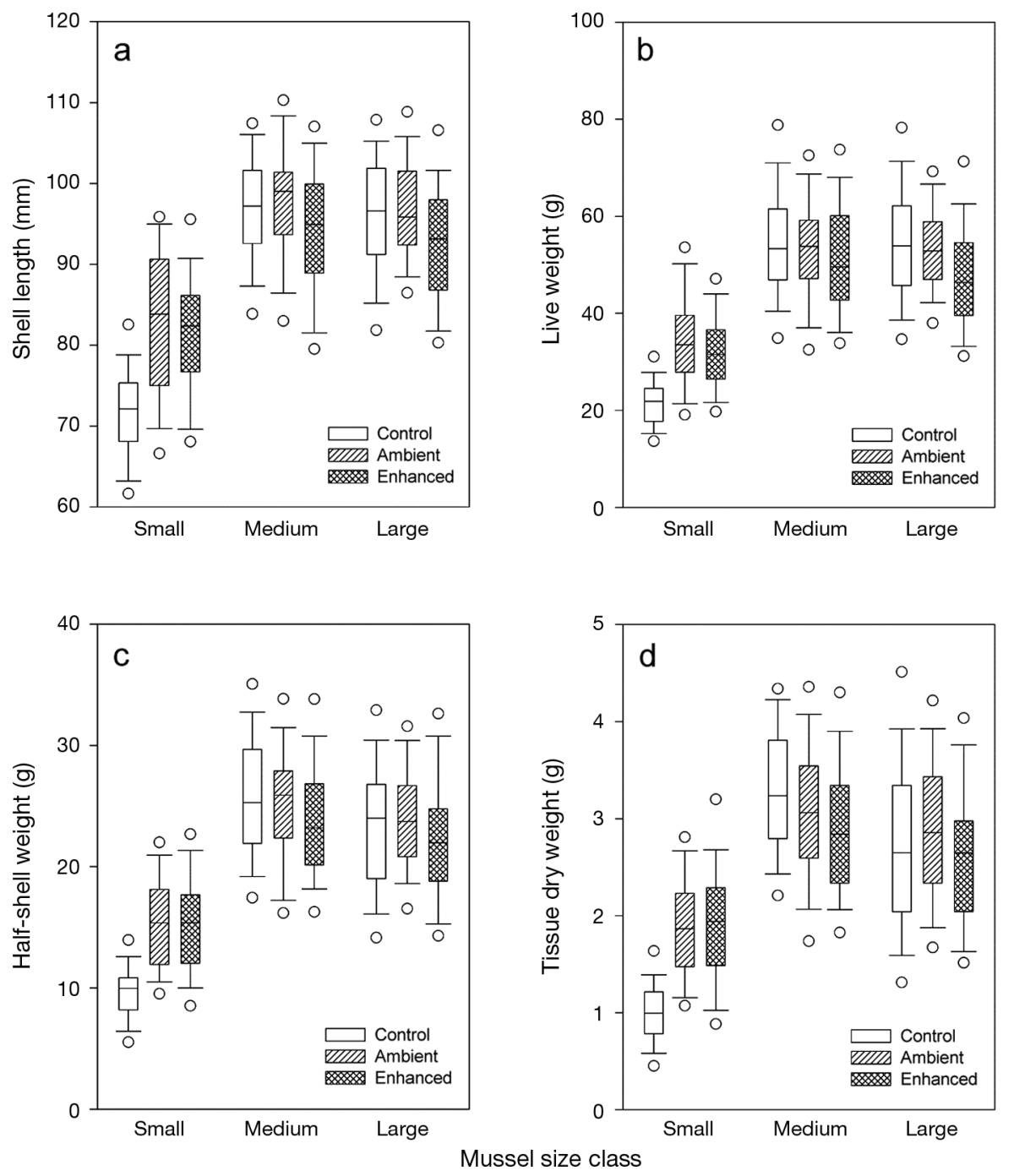

Fig. 6. Perna canaliculus. Various indices of individual mussel size: (a) shell length, (b) live weight, (c) half-shell weight, and (d) tissue dry weight for the 3 size classes (small: 20-40 mm shell length at deployment, medium: 40-60 $\mathrm{mm}$, and large: $60-70 \mathrm{~mm}$ ) and fouling treatments (controls, ambient fouling, and enhanced Didemnum vexillum fouling). Crossbar inside each box indicates median; lower and upper box limits represent the 25th and 75th percentiles, respectively; bottom and top whiskers represent 10th and 90th percentiles, respectively; while lower and upper circles represent 5th and 95th percentiles, respectively

vidual mussels within the ambient fouling (82.85 \pm $1.04 \mathrm{~mm}$ shell length and $34.41 \pm 1.10 \mathrm{~g}$ live weight) and enhanced fouling treatments $(81.53 \pm 0.89 \mathrm{~mm}$ shell length and $31.97 \pm 0.93 \mathrm{~g}$ live weight) were greater than in the controls $(71.95 \pm 0.66 \mathrm{~mm}$ shell length and $21.79 \pm 0.64 \mathrm{~g}$ live weight).
There was no apparent effect of fouling on mussel condition. Within each of the CI and GWI indices, condition values were similar across the 3 size classes of mussels, and across fouling treatments within each size class (Fig. 7). PERMANOVA analyses revealed highly significant spatial variability in both indices

Table 3. Perna canaliculus. Permutational ANOVAs testing for mussel size class and fouling treatment effects on shell length and live weight (see Fig. 6a,b). Analyses based on Euclidean distances of the untransformed data, and each term was tested using 999 random permutations of appropriate units. Significant values $(p<0.05)$ indicated in bold

\begin{tabular}{|c|c|c|c|c|c|c|c|}
\hline \multirow[t]{2}{*}{ Source } & \multirow[t]{2}{*}{$\mathrm{df}$} & \multicolumn{3}{|c|}{ - Shell length } & & \multirow{2}{*}{$\begin{array}{l}\text { Live weight } \\
\text { Pseudo-F }\end{array}$} & \multirow[b]{2}{*}{$\mathrm{p}($ perm $)$} \\
\hline & & MS & Pseudo- $F$ & $\mathrm{p}($ perm $)$ & MS & & \\
\hline Fouling & 2 & 1190.20 & 2.671 & 0.078 & 827.80 & 1.056 & 0.359 \\
\hline Size & 2 & 23411.00 & 52.540 & 0.001 & 42654.00 & 54.390 & 0.001 \\
\hline Fouling $\times$ Size & 4 & 1166.10 & 2.617 & 0.057 & 1975.00 & 2.518 & 0.071 \\
\hline Line $($ Fouling $\times$ Size) & 27 & 445.60 & 10.453 & 0.001 & 784.21 & 9.219 & 0.001 \\
\hline Residual & 684 & 42.60 & & & 85.07 & & \\
\hline Total & 719 & & & & & & \\
\hline
\end{tabular}



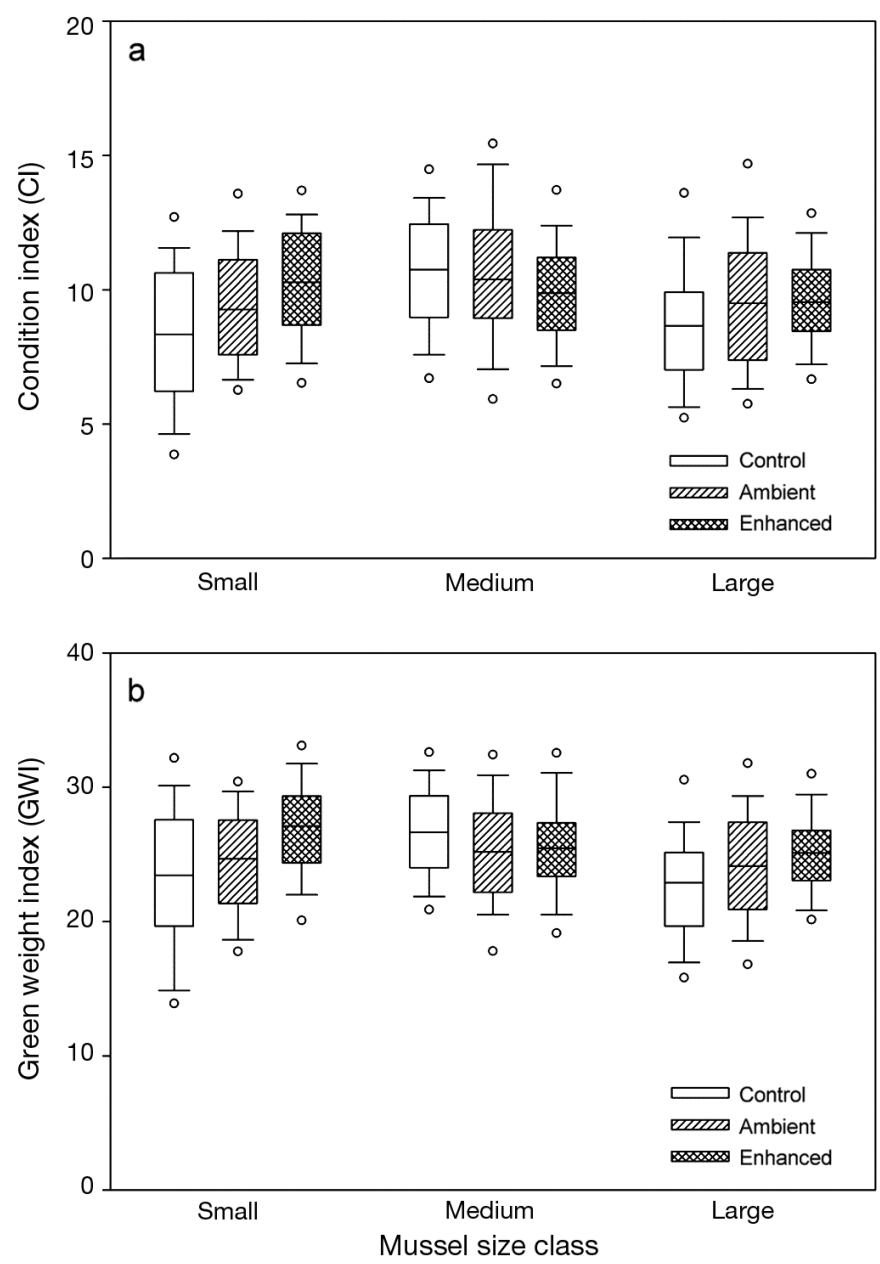

Fig. 7. Perna canaliculus. Individual mussel (a) condition index (CI) and (b) green weight index (GWI) for the 3 size classes (small: 20-40 mm shell length at deployment, medium: $40-60 \mathrm{~mm}$, and large: $60-70 \mathrm{~mm}$ ) and fouling treatments (controls, ambient fouling, and enhanced Didemnum vexillum fouling). Crossbar inside each box indicates median; lower and upper box limits represent the 25th and 75th percentiles, respectively; bottom and top whiskers represent 10th and 90th percentiles, respectively; while lower and upper circles represent 5th and 95th percentiles, respectively
(Line, $\mathrm{p}<0.01$; Table 4 ), but no significant effect of fouling treatment was detected for either CI ( $\mathrm{p}=$ 0.230; Table 4) or GWI ( $p=0.189$; Table 4). There was a significant effect of size class on CI $(p=0.042$; Table 4), but no significant difference in GWI ( $\mathrm{p}=$ 0.173; Table 4). Pairwise comparisons indicated significant differences in CI between the medium and large mussels only ( $p<0.01$ ). Linear regression analyses indicated no significant relationship between Didemnum vexillum biomass and both mussel CI $\left(r^{2}=0.110, p=0.079\right.$; Fig. 8a) and GWI $\left(r^{2}=0.023\right.$, $\mathrm{p}=0.431$; Fig. 8b).

\section{DISCUSSION}

\section{Fouling impacts on cultured mussels}

Despite the recognised threat of Didemnum vexillum biofouling to commercial shellfish industries globally (Daniel \& Therriault 2007, Valentine et al. 2007b, Cohen et al. 2011), there is a distinct lack of empirical data for direct impacts of $D$. vexillum fouling on cultured bivalves under industry conditions. Although only reflecting one study site, our results suggest that New Zealand green-lipped mussels are most vulnerable to direct $D$. vexillum impacts at early stages of mussel production. Additionally, negative impacts within our study system appear restricted to fouling-related displacement of smaller mussels as opposed to reduced growth and condition. The mussels remaining in the presence of $D$. vexillum and other fouling species in our study appear to have not been adversely affected by the overgrowth that occurred. These findings support the limited literature investigating direct impacts of colonial ascidians on cultured mussel species; impacts are often restricted to fouling-related crop losses and production costs, with little demonstrated impact on mussel productivity (e.g. Arens et al. 2011, Cordell et al. in press).

Table 4. Perna canaliculus. Permutational ANOVAs testing for mussel size class and fouling treatment effects on condition index and green weight index (see Fig. 7). Analyses based on Euclidean distances of the square-root-transformed data, and each term was tested using 999 random permutations of appropriate units. Significant values $(p<0.05)$ indicated in bold

\begin{tabular}{|c|c|c|c|c|c|c|c|}
\hline \multirow[t]{2}{*}{ Source } & \multirow{2}{*}{ df } & \multicolumn{3}{|c|}{ - Condition index } & \multicolumn{3}{|c|}{ - Green weight index } \\
\hline & & MS & Pseudo- $F$ & $\mathrm{p}($ perm $)$ & MS & Pseudo- $F$ & $\mathrm{p}($ perm $)$ \\
\hline Fouling & 2 & 1.238 & 1.678 & 0.230 & 2.131 & 1.761 & 0.189 \\
\hline Size & 2 & 2.505 & 3.396 & 0.042 & 2.212 & 1.829 & 0.173 \\
\hline Fouling $\times$ Size & 4 & 0.988 & 1.340 & 0.277 & 1.358 & 1.123 & 0.357 \\
\hline Line (Fouling $\times$ Size) & 27 & 0.738 & 6.030 & 0.001 & 1.210 & 8.703 & 0.001 \\
\hline Residual & 684 & 0.122 & & & 0.139 & & \\
\hline Total & 719 & & & & & & \\
\hline
\end{tabular}



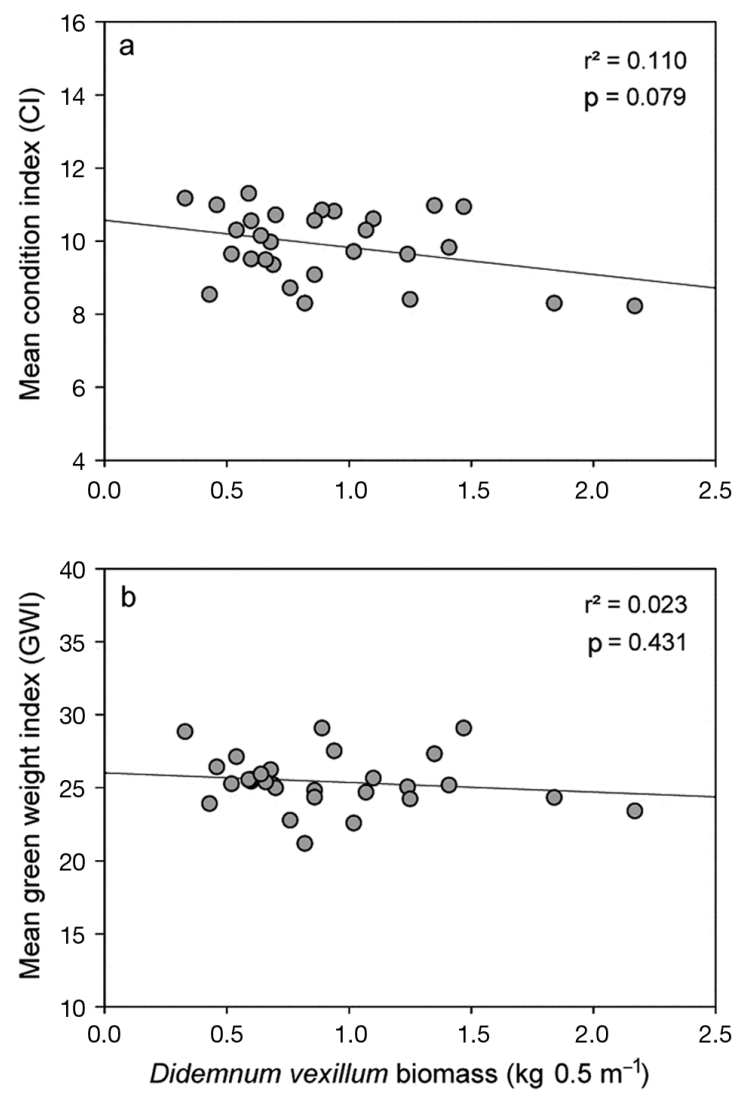

Fig. 8. Perna canaliculus and Didemnum vexillum. Relationship between (a) mean mussel condition index (CI) and (b) mean mussel green weight index (GWI) per $0.5 \mathrm{~m}$ section of mussel line and $D$. vexillum biomass present for each section. Results are pooled across mussel size classes ( $\mathrm{n}=29$ sections)

Significant reductions in mussel density due to increased fouling biomass were only recorded between treatments within the small mussel size class. Control lines within the small size class had significantly higher mussel density when compared to both the enhanced and ambient fouling treatments. The combined mussel weight within sections followed a similar pattern; however, the increased mussel density within the small control sections was not reflected in the combined weights for this treatment, indicating that although there were more mussels present overall, they were individually smaller. The effect of Didemnum vexillum on cultured mussel density and product weight has not been investigated elsewhere. However, a similar relationship was reported between the invasive ascidian Ciona intestinalis and the cultured blue mussel Mytilus edulis (Daigle \& Herbinger 2009). In that study, approximately two-thirds fewer live mussels (>45 mm) were recorded in highly fouled sections (100\% coverage) compared to those with low levels of fouling (0 to $10 \%$ coverage), although such comparisons have the potential to be confounded for reasons described in the next subsection.

Even once standardised for initial stocking density, the number of mussels lost was considerably greater from the small size class, and decreased with increasing mussel size. A higher loss recorded in the small size class is supported by the strong negative relationship between Didemnum vexillum biomass and small mussel density within individual sections, suggesting that small mussels at the study site were being displaced by $D$. vexillum and may be at more risk from overgrowth by this species. This relationship was also evident, although to a lesser extent, within the medium mussels. On the other hand, the apparent displacement by $D$. vexillum appears to be less of a threat to larger mussels ( $>40 \mathrm{~mm}$ ), based on the levels of $D$. vexillum fouling described in our study. The impact of fouling by the solitary ascidian Ciona intestinalis on blue mussel Mytilus galloprovincialis culture in southern Australia has also been shown to be size-specific, with mussel condition significantly lower in small mussels only (Sievers et al. 2013). Higher filtration rates and superior competition for resources in the larger mussels were hypothesised as the reason for the less pronounced reductions in flesh weights, and thus condition in the larger mussels (Sievers et al. 2013).

Due to the initial high stocking density of lines within the small mussel size class in the present study, it is possible the mussels underwent a process of self-thinning over the course of their deployment. Current industry practice involves stripping and reseeding mussels onto new ropes at lower densities once they reach approximately 40 to $50 \mathrm{~mm}$ shell length. This reseeding serves a dual purpose as it not only thins the mussels out to a more productive stocking density, but also removes or reduces the effects of biofouling (Woods et al. 2012). We did not incorporate this reseeding step into the present study because it would have caused the disruption and removal of fouling organisms. During our experiment, as mussels grew and available space became limited, byssal attachments may have been stressed by increased weight from fouling overgrowth. This may explain the lower level of mussel loss recorded for the control treatment within the small mussels, as the periodic removal of fouling present through freshwater treatments will have interrupted this process.

High levels of fouling on lines did not appear to directly affect individual mussel size or condition 
in our experiment. Mussels within the medium and large size classes had comparable shell lengths and live weights across fouling treatments at the conclusion of the study. However, control mussels within the small mussel size class were smaller in both shell length and live weight measurements, possibly due to increased intra-specific resource competition. That being so, the small control mussels did not appear to exhibit any negative effects on condition when compared to other treatment groups. The absence of a measurable effect on growth and condition of Perna canaliculus suggests that Didemnum vexillum is not adversely affecting the nature or quantity of food available to the mussels within our study system. This is most likely explained by differences in particle filtration capabilities of the 2 species and subsequent resource partitioning. Green-lipped mussels have a clearance particle range of 5 to $20 \mu \mathrm{m}$ (Safi \& Gibbs 2003), whereas colonial ascidians such as $D$. vexillum utilise very small particulate matter, primarily in the 0.5 to $2 \mu \mathrm{m}$ range (Bone et al. 2003).

In contrast to the present study, Auker (2010) reported unfouled blue mussels Mytilus edulis to have greater shell lengths and a higher tissue index (volume-based condition index) than those fouled by Didemnum vexillum in the northeast USA. Similarly, at the conclusion of a 5 mo study in British Columbia, Canada, cultured Pacific oysters Crassostrea gigas fouled by $D$. vexillum were also shown to have a lower condition index than those kept free of fouling through manual cleaning with soft-wire brushes (Switzer et al. 2011). However, the experimental set-up of both studies differed considerably from the research presented here; groups of mussels were held in plastic-wire mesh envelopes (as opposed to being attached to industry culture ropes as in our study), and oysters were grown in plastic trays. $D$. vexillum colonies in the Auker (2010) study were observed to overgrow the mesh of the envelopes as well as the mussels themselves, thus possibly obstructing water flow into the cages and thereby contributing to the lower growth rates observed (e.g. Uribe \& Etchepare 2002). Similarly, the plastic trays containing the fouled oysters in the Switzer et al. (2011) study were left undisturbed over the course of the deployment, with the exterior of the trays becoming fouled. The possibility that water flow obstruction was driving the differences in mussel and oyster condition is supported by data from an 'industry control' treatment in the Switzer et al. (2011) study, in which the plastic trays were replaced with clean trays midway through the experiment (mimicking standard industry practice). Despite being heavily fouled with
D. vexillum, oysters in this treatment were not found to have significantly different condition index values than oysters that were manually kept clean (Switzer et al. 2011).

\section{Broader considerations for inferring and assessing fouling impacts}

The results presented showed no direct effects of Didemnum vexillum fouling on mussel size and condition, but did indicate negative effects on the density of small mussels. However, additional factors need to be considered when assessing the wider implications of these findings. Mussel farms within the study region are known to accumulate a diverse range of biofouling organisms that can account for a considerable biomass on mussel ropes (Woods et al. 2012). Because the level of $D$. vexillum biomass on lines at the conclusion of the present study was comparable between ambient and enhanced fouling treatments, no difference in the effects between these treatments was observed. Hence, despite fragment inoculation quickly leading to a considerable D. vexillum cover (see Fig. 2a, b), ambient inoculation by $D$. vexillum larvae in the water column led to a similar level of $D$. vexillum fouling in the longer term (i.e. over the 15 mo experimental duration). Similarly, while the present study showed a negative relationship on small mussel density with increased $D$. vexillum biomass, the estimate of a $40 \%$ reduction in mussel density per kilogram of $D$. vexillum (based on the $0.5 \mathrm{~m}$ sections) should be treated with caution, as the biomass measurement reflected a point in time at the end of the experiment. The amount of D. vexillum would have differed greatly between seasons, and possibly inter-annually. More frequent assessment of fouling effects during the course of the study may have better elucidated direct impacts, and this approach is recommended for future research in this area.

In addition, although Didemnum vexillum was the dominant fouling species present on the ambient and enhanced treatment lines, particularly during summer months when this species experiences considerable colony growth (Valentine et al. 2007a), other fouling species were also commonly observed (e.g. the blue mussel Mytilus galloprovincialis and the seaweed Undaria pinnatifida). As such, the observed effects on mussel density and loss may not be exclusively attributable to D. vexillum overgrowth. By periodically treating the control lines with freshwater, all fouling was effectively removed. Ideally, a 
treatment involving manual removal of $D$. vexillum colonies alone (i.e. without freshwater) would have been incorporated, to investigate its importance relative to background fouling. However, given the rapid growth of $D$. vexillum, this step would need to have been undertaken frequently, and would have been prohibitively labour-intensive at the scale of the experiment.

Lastly, while fouling observed on the ambient and enhancement treatment lines was reasonably high, it was far less than some Didemnum vexillum infestations evident in nearby locations and at other times, as this species has been observed to completely smother mussels elsewhere in the region (Pannell \& Coutts 2007). Thus, it can be difficult to experimentally mimic worst-case invasiveness, even at adjacent locations. However, as the worst case is generally of most interest, many studies of biofouling attempt to infer potential impacts from a comparison of areas of high versus low levels of fouling (e.g. de Sa et al. 2007, Daigle \& Herbinger 2009, Fitridge 2011). Such assessment approaches can lead to ambiguous results, especially when the spatial and temporal variation of infestation and stochastic nature of the invasion process are considered (Forrest \& Taylor 2002, Padilla 2010). A recent review of the marine invasion literature found that the majority of fieldbased impact experiments are presence-absence designs, where it is unclear if impacts are caused by universal or causal agents (Thomsen et al. 2011). For instance, on mussel farms in the present study region, it is not certain that low mussel density in the presence of high $D$. vexillum biomass automatically reflects a displacement effect by $D$. vexillum; it could simply reflect that $D$. vexillum invaded bare space created by mussel drop-off or dislodgement (e.g. during industry handling of culture lines). In the present study, the fact that the control lines remained as an intact continuous column of mussels across all size classes provides confidence that the $D$. vexillum effect measured was real.

\section{Wider industry implications of fouling}

Impacts of biofouling on cultured shellfish operations are often varied, including negative effects on growth rates and meat yields, as well as lost revenue through stock mortality, crop losses, and increased costs of production and processing (Fitridge et al. 2012 and references therein). The level of fouling present within a marine farm can be substantial, with a recent assessment of 2 farms within the Marlbor- ough Sounds region indicating that a significant proportion (ca. $15 \%$ ) of total biomass present on mussel lines comprised biofouling species, even following reseeding of ropes between crop stages (Woods et al. 2012). A range of species-dependent effects of fouling in New Zealand culture regions have been reported. In the Marlborough Sounds, it has been estimated that mussel farms lose up to $15 \%$ of their seed stock through biofouling (Hembry 2008). Across New Zealand, impacts include direct effects on mussels during grow-out, physical effects on harvesting and product processing, as well as effects on product value through disfiguration of the mussel shell (e.g. Sinner et al. 2000, Heasman \& de Zwart 2004, Jeffs \& Stanley 2010).

Based on the observation that smaller mussel size classes were the most vulnerable to the negative effects of fouling, it is hypothesised that the Didemnum vexillum overgrowth would have had an even greater impact on very small mussel spat. A greater impact of fouling on spat and very small mussels is consistent with industry observations from growing areas. Among the problematic fouling species in addition to $D$. vexillum and other ascidians are indigenous blue mussels Mytilus galloprovincialis and macroalgae such as Colpomenia spp. As part of the present study, we attempted to quantify the effects of $D$. vexillum fouling on spat $(<5 \mathrm{~mm}$ shell length). However, this treatment was not successful due to the natural loss of some spat from the experimental lines, reflecting a wider industry problem with spat retention during the early stages of mussel grow-out. The loss of spat created gaps in our otherwise uniform 'sock' of mussels, which could have been readily colonised by $D$. vexillum, leading to inferred treatment effects where none existed.

Biofouling within shellfish aquaculture operations is an important management issue, and expenditure for control can be significant even at the individual farm level. An understanding of the impacts of fouling species, particularly across different stages of the production chain, is necessary for the implementation of successful management procedures. In the Marlborough Sounds aquaculture region, adoption of new industry practices, coupled with an apparent decline in the level of invasiveness of Didemnum vexillum over recent years, has led to adequate means of control at present. Management of $D$. vexillum biomass on crop lines through intermediate reseeding of lines has prevented the substantial crop losses observed in this region previously. However, further research on cost-effective treatment methods is required, as well as management of vector movements 
such as transfers of infected stock and equipment, in order to reduce the risk of spread to areas important for growing shellfish aquaculture seed-stock.

Acknowledgements. We are grateful to Javier Atalah, Grant Hopkins, Kirsty Smith, Therese Westbury, Anais LacoursiereRoussel and Lucie Bizzozero for their assistance with various aspects of the experiments and data analysis, as well as 3 anonymous reviewers whose helpful comments improved this manuscript. Sincere thanks are also expressed to Marlborough Mussel Company Ltd, in particular Aaron Pannell, who provided considerable logistic support for this project as well as invaluable information on the intricacies of Didemnum vexillum. This work was funded by the New Zealand Ministry of Business, Innovation and Employment under Contract PROJ-13785-PPS-CAW (Adding Value to New Zealand's Cultured Shellfish Industry: Maximising Profitability, Minimising Risk). L.M.F. was funded through a joint Cawthron Institute and New Zealand Tertiary Education Commission 'Bright Futures Enterprise PhD Scholarship'.

\section{LITERATURE CITED}

Adams CM, Shumway SE, Whitlatch RB, Getchis T (2011) Biofouling in marine molluscan shellfish aquaculture: a survey assessing the business and economic implications of mitigation. J World Aquacult Soc 42:242-252

Anderson MJ (2001) A new method for non-parametric analysis of variance. Austral Ecol 26:32-46

Anderson MJ, Gorley RN (2007) PERMANOVA+ for PRIMER: guide to software and statistical methods. PRIMER-E, Plymouth

> Arens CJ, Paetzold SC, Ramsay A, Davidson J (2011) Pressurized seawater as an antifouling treatment against the colonial tunicates Botrylloides violaceus and Botryllus schlosseri in mussel aquaculture. Aquat Invasions 6: 465-476

Auker LA (2010) The effects of Didemnum vexillum overgrowth on Mytilus edulis biology and ecology. PhD thesis, University of New Hampshire, Durham

- Blum JC, Chang AL, Lijesthröm M, Schenk ME, Steinberg MK, Ruiz GM (2007) The non-native solitary ascidian Ciona intestinalis (L.) depresses species richness. J Exp Mar Biol Ecol 342:5-14

Bone Q, Carre C, Chang P (2003) Tunicate feeding filters. J Mar Biol Assoc UK 83:907-919

Boothroyd FA, MacNair NG, Landry T, Locke A, Davidson TJ (2002) Dealing with an aquatic invader: the clubbed tunicate (Styela clava) in Prince Edward Island waters. Bull Aquacult Assoc Can 102:98-99

> Claereboudt MR, Bureau D, Cote J, Himmelman JH (1994) Fouling development and its effect on the growth of juvenile giant scallops (Placopecten magellanicus) in suspended culture. Aquaculture 121:327-342

Clarke KR, Gorley RN (2006) PRIMER v6.1.6: user manual/ tutorial. PRIMER-E, Plymouth

> Cohen CS, McCann L, Davis T, Shaw L, Ruiz G (2011) Discovery and significance of the colonial tunicate Didemnum vexillum in Alaska. Aquat Invasions 6:263-271

Cordell JR, Levy C, Toft JD (in press) Ecological implications of invasive tunicates associated with artificial structures in Puget Sound, Washington, USA. Biol Invasions, doi: 10.1007/s10530-012-0366-y

> Coutts ADM, Forrest BM (2007) Development and application of tools for incursion response: lessons learned from the management of the fouling pest Didemnum vexillum. J Exp Mar Biol Ecol 342:154-162

Daigle RM, Herbinger CM (2009) Ecological interactions between the vase tunicate (Ciona intestinalis) and the farmed blue mussel (Mytilus edulis) in Nova Scotia, Canada. Aquat Invasions 4:177-187

Daniel KS, Therriault TW (2007) Biological synopsis of the invasive tunicate Didemnum sp. Can Manuscr Rep Fish Aquat Sci 2788. Fisheries and Oceans Canada, Ottawa

> Davis MH, Davis ME (2010) The impact of the ascidian Styela clava Herdman on shellfish farming in the Bassin de Thau, France. J Appl Ichthyol 26(Suppl S2):12-18

Dealteris JT, Kilpatrick BD, Rheault RB (2004) A comparative evaluation of the habitat value of shellfish aquaculture gear, submerged aquatic vegetation and a nonvegetated seabed. J Shellfish Res 23:867-874

> Denny CM (2008) Development of a method to reduce the spread of the ascidian Didemnum vexillum with aquaculture transfers. ICES J Mar Sci 65:805-810

> de Sa FS, Nalesso RC, Paresgue K (2007) Fouling organisms on Perna perna mussels: is it worth removing them? Braz J Oceanogr 55:155-161

Enright C (1993) Control of fouling in bivalve aquaculture. World Aquacult 24:44-46

Fitridge I (2011) The ecology of hydroids (Hydrozoa: Cnidaria) in Port Phillip Bay, Australia, and their impacts as fouling species in longline mussel culture. $\mathrm{PhD}$ thesis, University of Melbourne

> Fitridge I, Dempster T, Guenther J, de Nys R (2012) The impact and control of biofouling in marine aquaculture: a review. Biofouling 28:649-669

Fletcher LM, Forrest BM, Atalah J, Bell JJ (2013) Reproductive seasonality of the invasive ascidian Didemnum vexillum in New Zealand and implications for shellfish aquaculture. Aquacult Environ Interact 3:197-211

Forrest BM, Blakemore KA (2006) Evaluation of treatments to reduce the spread of a marine plant pest with aquaculture transfers. Aquaculture 257:333-345

Forrest BM, Taylor MD (2002) Assessing invasion impact: survey design considerations and implications for management of an invasive marine plant. Biol Invasions 4 : 375-386

Fox SP (2003) The growth of cultured Perna canaliculus in Pelorus Sound, New Zealand: the importance of spat origin, environment, and time of harvest. PhD thesis, University of Canterbury, Christchurch

Heasman K, de Zwart E (2004) Preliminary investigation on Amphisbetia bispinosa colonisation on mussel farms in the Coromandel. Cawthron Report 928. Cawthron Institute, Nelson

Hembry O (2008) Squirt squirted. The New Zealand Herald, 7 April. Available at www.nzherald.co.nz/business/news/ article.cfm?c_id $=3 \&$ objectid $=10502376$

Hickman RW, Illingworth J (1980) Condition cycle of the green-lipped mussel Perna canaliculus in New Zealand. Mar Biol 60:27-38

Jeffs A, Stanley J (2010) The occurrence of barnacles on Coromandel mussel farms: a preliminary report for Sealord Shellfish Ltd. Leigh Marine Laboratory, University of Auckland

Kott P (2002) A complex didemnid ascidian from Whangamata, New Zealand. J Mar Biol Assoc UK 82:625-628 
Lambert G (2007) Invasive sea squirts: a growing global problem. J Exp Mar Biol Ecol 342:3-4

Lane A, Willemsen P (2004) Collaborative effort looks into biofouling. Fish Farming Int, September, p 34-35

Le Blanc AR, Landry T, Miron G (2003) Fouling organisms of the blue mussel Mytilus edulis: their effect on nutrient uptake and release. J Shellfish Res 22:633-638

Lesser M, Shumway S, Cucci T, Smith J (1992) Impact of fouling organisms on mussel rope culture: interspecific competition for food among suspension-feeding invertebrates. J Exp Mar Biol Ecol 165:91-102

Lodeiros CJM, Himmelman JH (1996) Influence of fouling on the growth and survival of the tropical scallop, Euvola (Pecten) zic zac (L. 1758) in suspended culture. Aquacult Res 27:749-756

McKindsey CW, Landry T, O'Beirn FX, Davies IM (2007) Bivalve aquaculture and exotic species; a review of ecological considerations and management issues. J Shellfish Res 26:281-294

> Morris JA Jr, Carman MR (2012) Fragment reattachment, reproductive status, and health indicators of the invasive colonial tunicate Didemnum vexillum with implications for dispersal. Biol Invasions 14:2133-2140

Padilla DK (2010) Context dependent impacts of non-native ecosystem engineers, the Pacific oyster Crassostrea gigas. Integr Comp Biol 50:213-225

Pannell A, Coutts ADM (2007) Treatment methods used to manage Didemnum vexillum in New Zealand. Report prepared for Biosecurity New Zealand. New Zealand Marine Farming Association, Blenheim

Railkin AI (2004) Marine biofouling: colonization process and defences. CRC Press, London

Ramsay A, Davidson J, Landry T, Arsenault G (2008) Process of invasiveness among exotic tunicates in Prince Edward Island, Canada. Biol Invasions 10:1311-1316

Riisgård HU, Christensen PB, Olesen NJ, Petersen JK, Moller MM, Anderson P (1995) Biological structure in a shallow cove (Kertinge Nor, Denmark). Control by benthic nutrient fluxes and suspension-feeding ascidians and jellyfish. Ophelia 41:329-344

Rocha RM, Kremer LP, Baptista MS, Metri R (2009) Bivalve cultures provide habitat for exotic tunicates in southern Brazil. Aquat Invasions 4:195-205

Ross KA, Thorpe JP, Brand AR (2004) Biological control of fouling in suspended scallop cultivation. Aquaculture 229:99-116

Safi KA, Gibbs MM (2003) Importance of different size

Editorial responsibility: Megan La Peyre,

Baton Rouge, Louisiana, USA classes of phytoplankton in Beatrix Bay, Marlborough Sounds, New Zealand, and the potential implications for aquaculture of the mussel, Perna canaliculus. NZ J Mar Freshw Res 37:267-272

Scheer BT (1945) The development of marine fouling communities. Biol Bull (Woods Hole) 89:103-112

> Sievers M, Fitridge I, Dempster T, Keough MJ (2013) Biofouling leads to reduced shell growth and flesh weight in the cultured mussel Mytilus galloprovincialis. Biofouling 29:97-107

Sinner J, Forrest BM, Taylor MD (2000) A strategy for managing the Asian kelp Undaria: final report. Cawthron Report 578. Cawthron Institute, Nelson

Su Z, Xiao H, Yan Y, Huang L (2008) Effect of fouling organisms on food uptake and nutrient release of scallop (Chlamys nobilis, Reeve) cultured in Daya Bay. J Ocean Univ China 7:93-96

> Switzer SE, Therriault TW, Dunham A, Pearce CM (2011) Assessing potential control options for the invasive tunicate Didemnum vexillum in shellfish aquaculture. Aquaculture 318:145-153

Thompson R, MacNair N (2004) An overview of the clubbed tunicate (Styela clava) in Prince Edward Island. Fish Aquacult Tech Rep 234. PEI Department of Agriculture, Fisheries, Aquaculture and Forestry, Charlottetown

Thomsen MS, Wernberg T, Olden JD, Griffin JN, Silliman BR (2011) A framework to study the context-dependent impacts of marine invasions. J Exp Mar Biol Ecol 400: 322-327

Uribe E, Etchepare I (2002) Effects of biofouling by Ciona intestinalis on suspended culture of Argopecten purpuratus in Bahia Inglesa, Chile. Bull Aquacult Assoc Can 102:93-95

Valentine PC, Carman MR, Blackwood DS, Heffron EJ (2007a) Ecological observations on the colonial ascidian Didemnum sp. in a New England tide pool habitat. J Exp Mar Biol Ecol 342:109-121

> Valentine PC, Collie JS, Reid RN, Asch RG, Guida VG, Blackwood DS (2007b) The occurrence of the colonial ascidian Didemnum sp. on Georges Bank gravel habitat - ecological observations and potential effects on groundfish and scallop fisheries. J Exp Mar Biol Ecol 342: $179-181$

Woods CMC, Floerl O, Hayden BJ (2012) Biofouling on Greenshell ${ }^{\mathrm{TM}}$ mussel (Perna canaliculus) farms: a preliminary assessment and potential implications for sustainable aquaculture practices. Aquacult Int 20:537-557

Submitted: November 30, 2012; Accepted: April 5, 2013 Proofs received from author(s): May 16, 2013 